\title{
PARENTING SOCIALIZATION: EFFORTS TO PROVIDE PARENT TRAINING AT BIMBINGAN BELAJAR CERIA KARAWACI , TANGERANG
}

\author{
Jossapat Hendra Prijanto ${ }^{1}$, Juliana Tirza ${ }^{2}$ \\ ${ }^{1}$ Pendidikan IPS, Universitas Pelita Harapan \\ ${ }^{2}$ Pendidikan IPS, Universitas Pelita Harapan \\ email jossapat.hendra@uph.edu, email mj.tirza@gmail.com
}

\begin{abstract}
Abstrak
Home care and education at school are essential pillars of child development. Economic conditions, geographical position, educational background of parents, and the stigma that develops in society towards women who do not need to be highly educated have a significant effect on parenting patterns, especially mother-to-child care. Not all Indonesian children receive proper care. Data from the National Service Agency (KOMNAS) for Children in 2006 showed that there was still 1,124 violence against children, 433 children experienced physical violence and 106 experienced psychological violence. Various alarming facts about the concern for Indonesian children have encouraged UPH Lecturers to contribute to community service to provide training for parents of students at Bimbingan Belajar Ceria Karawaci, Tangerang. They come from families with low levels of education and difficulties. It is hoped that this training activity can provide insight into their parents and have an impact on the mindset of the community around Bimbingan Belajar Ceria regarding proper parenting for their children. Various efforts were made in community service in Bimbingan Belajar Ceria, stated in this paper. This paper aims to share awareness about the parental training efforts that have been carried out by Pelita Harapan University lecturers, with the hope of forming a smart and stable society. The result of this community service is that the parents get many parental skills, and the feedback is positive even they want this program to be continued and give more knowledge for them.
\end{abstract}

Keywords: parenting, community service, education

\section{PENDAHULUAN}

Parents are responsible for developing children's existential abilities, reaching all children's needs through care, nurturing, speech and treatment. All the fundamental processes of forming a child are born from interactions in their immediate environment, namely parents, then other family members (Khairuddin, 2008). Parent in parenting has several definitions - mother, father, someone who will guide in a new life, a carer, or a guardian. The parent is someone who accompanies and shows all stages of a child's swelling, who nourishes, protects, conducts the child's new life at every stage of his development (Brooks, 2001). Definite parenting from an early age on a child will be very substantial when the child grows up even when he gets married and becomes a parent. Positive education for children should begin from the time the baby is in the womb. Starting from small things by asking the fetus to talk, pray, do good things and, preferably during pregnancy, not stress. Because the mother who is stressed will also affect the development of the fetus if the mother cannot control her emotions. Positive caregivers are closely related to the ability of a family/household and community to give attention, 
time and support to meet the physical, mental and social needs of children who are growing and for other family members (Engel, 1997). Hoghughi said that parenting involves a variety of activities aimed at making children grow optimally and persevere well. The principle of parenting, according to Hoghughi does not emphasize who (the perpetrator) but instead emphasizes the activities of children's development and education. (Hoghughi, 2004). Therefore, care includes physical care, emotional care and social care. Social care is critical because the social relationships that are built-in parenting will form a perspective on themselves and their environment. Excellent social care sharpens on providing assistance to children to be well integrated with their home and school setting and helping to train children about responsibility social must be brought out (Hoghughi, 2004). Brooks (2001) also describes parenting as a method that leads to a series of actions and interactions that parents take to encourage children's development. The parenting process is not a one-way connection in which parents influence kids. However, more than that, parenting is a process of interaction between parents and children that is influenced by the culture and social institutions in which the child is raised (Brooks, 2001).

Ideally, parents become characters who guard and provide children before they can overlook the journey in society as independent individuals. The fact is that there are still many low-income households in Indonesia who are not sufficiently educated before enhancing parents; as a result, children who are born become victims of improper parenting. In urban areas, the poor are characterized by the head of the family working in the informal sector, having low education, living in disaster-prone slum settlements, not having strong housing ownership guarantees and a larger number of family members than the non-poor. This family poverty situation has an impact on the growth and development of their children.

Suyanto's (2013) research results show that poor children in urban areas are threatened with marginalization, exploitation and have no future because they are prone to dropping out of school, do not receive assistance when experiencing academic difficulties, lack of parental appreciation for education, and are forced to work for a living
(Suyanto, 2013). Has a significant adverse effect on completion of education up to secondary school level; Scholastic ability does not play a role in ensuring the completion of secondary school but is an essential factor in increasing children's chances of graduating from high school (Suryadarma, 2013).

This phenomenon has captured the attention of some lecturers in social science education programs, Teachers Colleges, Pelita Harapan University to find solutions through training parents of students in informal learning programs around campus. The program taken out is in the form of parenting, sharing insights and experience for families in the neighbourhood.

\section{METODE}

This parenting activity is carried out in several stages, such as,

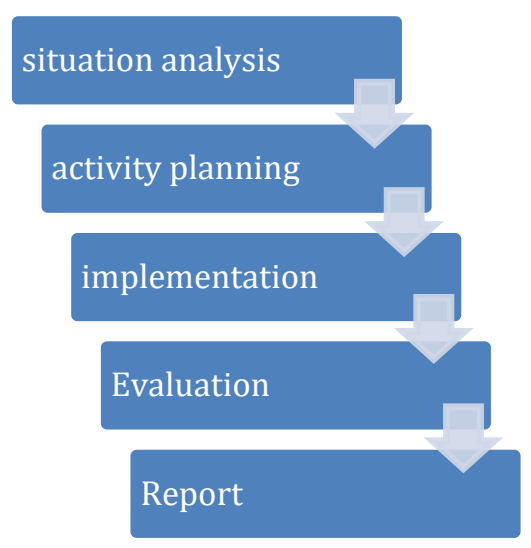

This parenting outreach project was held at the Bimbingan Belajar Ceria in Karawaci area, Tangerang throughout the campus. This project is offered out during the even semester with specific caps on sanitation, financial management and parenting for children.

\section{HASIL DAN PEMBAHASAN}

In Indonesia, the number of low-income families is still relatively large. The tremendous economic demands to meet family needs make many parents, both fathers and mothers, have to work outside the home, resulting in low interaction with family members and reduced time to enjoy togetherness. Poverty and lifestyle are often the causes of family crises.

$$
\text { Pendidikan }
$$


Economic calamity is a force that continues to the mental strain of parents so that it can influence the mental health of parents (Ward, 2014). Lowincome families face economic pressure, which creates a high level of stress on parents, which then spills out on the marriage relationship and the role of parenthood (Magnuson, 2009). The quality of parenting is crucial for child development, where risk factors due to socio-economic situations can be mediated by these qualities. The following results show the importance of the role and involvement of parents in children's academic achievement.

According to the Framework for the Assessment of Children in Need and their Families used by the Ministry of Health in the United Kingdom (White, 2005) parental guardianship range holds six dimensions, particularly primary care, assuring security, emotional warmth, stimulation, guidance and boundaries, and confidence. While the enabling factors are support (a socio-economic situation, home condition), and family participation (quantity and quality of time, parents communicate with children).

The necessity of parents to work executes the socio-economic circumstances covered by these families gives them powerless to guarantee a child's life that is prosperous, stable, safe and happy. Several lecturers then took the initiative to share insights about financial management. In this material, basic knowledge about how to manage finances wisely is shared. In this material, the tricks to manage money are not much but can meet all the needs of the family.

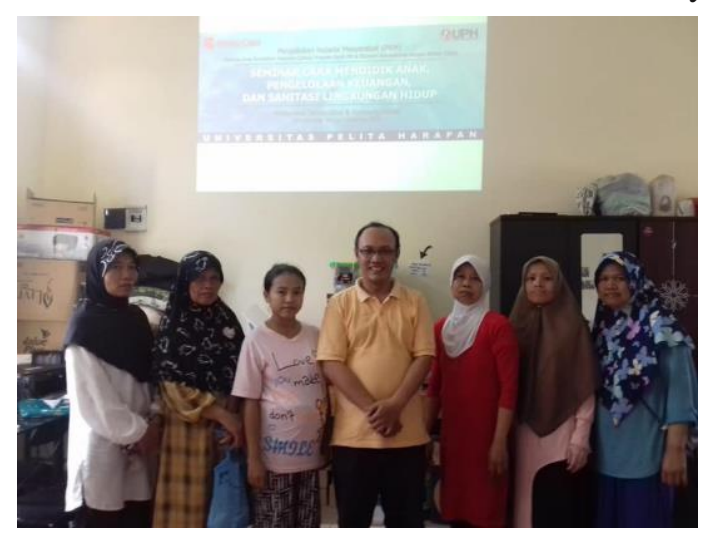

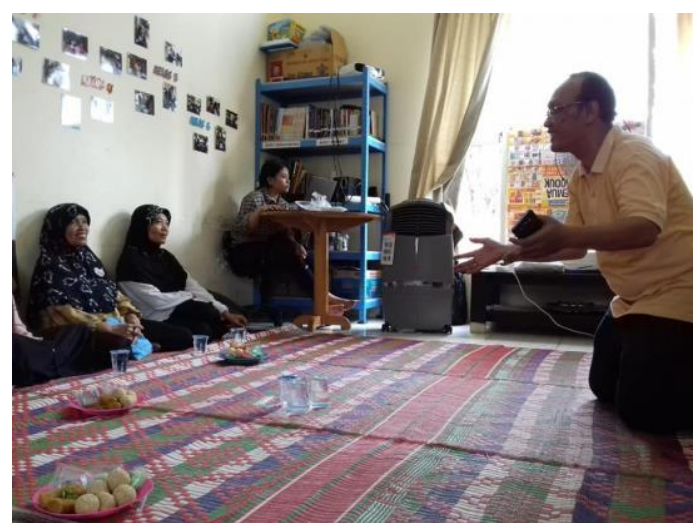

Figure 1. (Parenting session)

Figure 2. (interaction during the session)

Financial management is considered crucial because not many parents are aware of this. This deficiency triggers debt which leads to repayment difficulties. Family life is not harmonious. Not a few families decide to divorce due to financial problems. If divorce has occurred, then the parenting process will certainly not run optimally. Children will also become sad and face difficulties in the future.

In addition to the socialization of financial management, the lecturer also shared insights on sanitation. It does not need a luxurious house or lives in a luxurious environment to guarantee sanitation. This topic is interesting to discuss in parenting programs because a healthy and clean environment affects the application of good habits in the family. Knowledge of sanitation includes how to dispose of garbage or waste management at home. The importance of waste management from home itself is the first step in ensuring a healthy and clean home life.

Parenting specifically discusses how to deal with a wayward child. This is considered necessary because whether a child is recalcitrant is often a reference for family harmony. Stubbornness arises from primary unmet needs. The primary needs of children include love, acceptance, nurture and food. Affection is of course very important for children. They will feel comfortable in a family that loves and 
loves them. Acceptance is still part of love. If parents reject the child, the child will try to seek attention or even become negative in the hope of receiving a sense of acceptance from the family. Parenting is still part of love. Children without good care will become children who lose direction and purpose. This will have a negative impact in the future. Children can lose their way and seek escape from things that are not good for them because they previously did not receive proper care. Food is also considered essential. Children who receive fair and adequate nutrition will help their cognitive development. With good cognitive development, children will be able to compete in producing works. Cognitive development will have a positive impact on children in the future.

Some of the reasons children become stubborn include pain, boredom, hunger or sleepiness. The way to overcome this includes giving children time if they are bored, find out the cause of the pain and treat it, invite him to eat together. Let him know when he is too tired and needs sleep. Another reason for children to be naughty is that they do not understand clear boundaries. Because the parents are busy working, eventually the child does not understand the limits he acts on, which makes the child behave negatively. Those are some of the things that are shared in the parent education program in this Bimbingan Belajar Ceria.

\section{KESIMPULAN}

Learning activities "Cheerful" tutoring, has been running better, in terms of facilities and tutors. Next, it is also hoped that UPH FIP-TC lecturers will continue to contribute, both in the educational process and in counselling that is useful for the surrounding community.

It is hoped that this group learning project can continue/be continued in the form of cooperation between the UPH FIP-TC and the Cheerful Bimbel. By still paying attention to all the obstacles or difficulties that hinder or interfere with the teaching and learning process, training for parents and field access is expected to be immediately responded to and handled by both parts, both through tutors and PIC Bimbel Ceria as well as direct action from each part.
The Teaching and Learning Process Activities at Bimbel Ceria are carried out one year two times, namely in the even and odd semesters, and are held every Sunday. Besides, socialization/coaching is also carried out to parents of students. The teaching at this cheerful tutoring is carried out to improve students 'academic abilities, students' enthusiasm for learning, and inspire the surrounding community to care and help improve the quality of education of children around Taman Ubud, especially Karawaci, Tangerang. Then for the socialization of guidance to parents, it is focused on child care and financial management that affects family welfare, as well as awareness of the importance of sanitation.

\section{REFERENCES}

Brooks, J. (2001). The Process Of Parenting. Yogyakarta: Pustaka Belajar.

Engel, J. .. (1997). Consumer behaviour. Mason: Permissions Department.

Hoghughi, M. S. (2004). Handbook of parenting: Theory and Research for Practice. India: SAGE Publications.

Khairuddin. (2008). Sosiologi Keluarga. Yogyakarta: Liberty.

Magnuson, K. \&.-D. (2009). Enduring influences of childhood poverty. Focus, 50-62, 26 (2).

Suryadarma, D. S. (2013). The contrasting role of ability and poverty on education attainment: evidence from indonesia. Indonesia: SMERU.

Suyanto, B. (2013). Anatomi kemiskinan dan strategi penanganannya. Malang: In-TRANS Publishing.

Ward, H. B.-D. (2014). Assessing parental capacity to change when Children are on the edge of care: an overview of current research evidence. Research Report. UK: Department of Education.

White, A. (2005). Assessment of parenting capacity. NSW: Centre for Parenting and Research. 